\title{
Analysis of Piano Curriculum Education and Cultivation of Creative Thinking Ability
}

\author{
Jing Li \\ College of Art, Yangtze University, Jingzhou, 434000, China
}

\begin{abstract}
Under the background of the new curriculum reform, combining the cultivation of creative thinking ability with piano curriculum education will help the school to cultivate more high-quality and innovative talents. At the same time, the cultivation of students' creative thinking ability in piano course education conforms to the demand of high-quality talents in the new era, and better implements the requirements of quality-oriented education on students' comprehensive quality and ability. Based on the significance of piano curriculum education to the cultivation of students' creative thinking ability, this paper puts forward the problems existing in piano curriculum education at the present stage, and puts forward effective countermeasures on this basis.
\end{abstract}

Keywords: piano education; ability to think creatively; cultivate

\section{Introduction}

As an important part of China's education system, piano curriculum education needs to strengthen the cultivation of students' creative thinking ability. Under the new era, improve students' creative thinking ability in the process of learning the piano is beneficial to promote the comprehensive development of students' comprehensive quality, to fully implement the innovative talent training goal, to maximize the satisfaction of the students' learning in the piano course education demand, further to make the students creative thinking ability can keep pace with The Times, and constantly improve the quality of the piano teaching.

\section{The Significance of Cultivating Creative Thinking Ability in Piano Curriculum Education}

In the process of comprehensively promoting the student-centered, piano curriculum education should fully implement the teaching task of cultivating students' self-confidence and comprehensive ability. The cultivation of students' creative thinking ability is conducive to the development of students' creativity and imagination in piano courses on the basis of learning piano playing skills well. In addition, there is a close relationship between piano curriculum education and creative thinking ability. In the process of piano learning, students should not only have professional skills, but also integrate their sincere feelings for piano works into performance, so that the music can attract and move the audience more. In this process, students are required to give full play to their creative thinking, constantly improve their piano performance ability and ability to feel music works, so as to effectively improve the quality and efficiency of learning.

\section{The Main Problems Existing in Piano Curriculum Education at Present Stage}

At present, the problems exposed in piano curriculum education restrict and hinder the cultivation of students' creative received basic knowledge, so they pay too much attention to the training of piano playing skills and neglect the imparting

Copyright (C) 2019 by author(s) and Frontier Scientific Research Publishing Inc.

This work is licensed under the Creative Commons Attribution International License (CC BY 4.0).

http://creativecommons.org/licenses/by/4.0/ 
of basic theoretical knowledge in the teaching process. In addition, some teachers skip the teaching of basic knowledge to complete the course schedule. The lack of systematic cultivation of basic theoretical knowledge will not only make students' piano literacy generally low, but also lead to low-level mistakes in piano playing and performance, which will affect the further improvement of piano teaching quality. Second, the lack of innovation in teaching methods and contents. Although the piano curriculum education in many schools is constantly innovating and developing, the teaching content still cannot keep up with the pace of cultivating students' creative thinking ability and music quality, resulting in the teaching effect is difficult to achieve the desired goal. Under the influence of traditional examination-oriented education, piano course education still adopts the teaching methods of infusing and teaching based on one classroom, one piano and one textbook, but lacks the cultivation of students' piano improvisation and interest. The teacher-led piano teaching leads to the low and boring teaching atmosphere in class, which makes it difficult to arouse students' interest in piano learning. Therefore, in order to promote the cultivation of students' creative thinking ability, the teachers need to evaluate the situation and innovate the teaching methods and contents. Third, the separation of teaching theory and practice. As a course combining theory and practice, piano needs to strengthen the practical teaching to students. From the current situation, the teacher only simply combs and explains the theoretical knowledge to the students, and does not actively carry out the corresponding piano practice activities, so that the students simply understand the skills and points related to the piano. This is not conducive to the development of students' creativity and imagination, but also affects the cultivation of students' music quality and comprehensive ability.

\section{The Cultivation Strategy of Creative Thinking Ability in Piano Curriculum Education}

4.1 Adhere to the concept of student-centered teaching

In order to train students' creative thinking ability under the background of quality education, it is necessary to adhere to the student-centered teaching concept, so as to better implement the teaching principle of morality and cultivating people. First of all, teachers should have the courage to abandon the traditional teaching ideas and concepts in the teaching process, and actively learn new teaching concepts and principles, so as to create a good teaching atmosphere and environment for students and promote good communication with students. Second, teachers should give students more opportunities to express their own views and suggestions, constantly stimulate students' thirst for knowledge, so that students can better play their creativity and thinking ability. For example, teachers can understand the era background of the work and collect related music story first, then use multimedia broadcast music video and pictures to the interpretation of all aspects of the piano works, in order to attract the attention of the students and help students into the classroom atmosphere, make the minds of students become more active, in order to further develop students' creative thinking ability and imagination to lay the foundation. Finally, in order to meet the needs of different students, teachers should also strengthen communication with students, clarify the problems and deficiencies in the learning process, and cultivate students' creative thinking ability from multiple aspects.

\subsection{Teaching piano works with new elements}

To cultivate students' creative thinking ability, teachers should actively use new elements in teaching. By combining the piano works with new elements, it is helpful to broaden and improve the teaching content of piano course. On the one hand, teachers can integrate some classical works on the basis of piano playing. For example, music creation and basic theories in classical works can enhance students' understanding and identification of piano, enrich students' knowledge constantly, so that students can consciously play their creativity to learn piano based on classical works. At the same time, teachers can also integrate some simple jazz, blues and other forms of piano works into teaching, and constantly cultivate students' musical literacy and comprehensive ability, so as to maximize the goal of cultivating students' creative thinking. 
On the other hand, when using new elements, teachers can also combine music teaching materials for primary and secondary schools and share some contents of impromptu accompaniment and songs easy to play and simple melody with students according to their interests, so as to cultivate students' creative thinking ability from multiple aspects.

4.3Adopt a variety of ways to cultivate thinking ability

To cultivate students' creative thinking ability, teachers should adopt various training methods, give full play to students' divergent thinking and inspiration thinking, and effectively promote the improvement of students' comprehensive ability. First, teachers can use the method of interrogative teaching to guide students to dare to question and challenge problems. Second, teachers can also use group cooperative teaching to cultivate and stimulate students' creative thinking ability. For example, when teaching Beethoven's sonata pathetique, the teacher may first play a video or picture of the pianist's performance for the students. Then, the group discussion is adopted to guide students to analyze the theme and structure of the work, so as to arouse students' enthusiasm and initiative, so that students can better play their thinking and innovation ability in the process of interaction and communication. Third, we should actively carry out piano performance activities and music activities to cultivate students' creative thinking ability. For example, when learning the accompaniment of songs, teachers can guide students to make use of what they have learned to create and edit the style, melody and characteristics of songs in the form of competitions, which not only conforms to the style of songs, but also has its own unique style of accompaniment, so as to effectively improve students' learning efficiency and realize the cultivation of students' creative thinking ability.

\section{Conclusions}

In short, in the process of piano teaching, teachers should improve the cultivation of students' creative thinking ability, actively adopt diversified teaching methods and teaching ideas, so that piano education can better develop and innovate.

\section{Conflicts of Interest}

The author declares no conflicts of interest regarding the publication of this paper.

\section{References}

[1] Xiong X. (2016). The Training of Classical Works and the Cultivation of Creative Thinking Ability in Piano Teaching. Music Space-time, 4, 118-119.

[2] Zhou X.L. (2019). Cultivation of Students' Innovative Thinking in Piano Teaching. Art Evaluation, 9, 127-128.

[3] Chen Y.W. (2018). Problems and Countermeasures in the Teaching of Impromptu Accompaniment for Piano in College Music Education. Yihai, 3, 101-103.

[4] Shang R. (2017). The Cultivation Strategy of Students' Innovation Ability in College Piano Teaching. Northern Music, 37(05),151-152.

[5] Dong S.Y. (2015). On the Necessity of Cultivating Students' Ability of Improvisation in College Music and Piano Teaching. Art and Technology,28(02):246. 